\title{
Dynamics of Style and Technique: a Reading of Hemingway's The Old Man and the Sea
}

\author{
${ }^{1}$ Dr. Chittaranjan Bhoi \\ Associate Professor of English \\ Hi-Tech College of Engineering \\ Bhubaneswar, Odisha
}

\begin{abstract}
Hemingway is distinctly different from his contemporaries for his abruptness of style and uniqueness of technique. The simplicity of diction and plausibility of annunciation in his fictions are very arresting. The clarity of precision and directness of approach are perhaps the most prominent traits of his novels. Articulation of personal experience is well established in his novels too. The dialogic approach indeed makes his fictions more delicious. The characters of his novels give the impression that they are engaged in live-talks as they exchange dialogue among themselves. The expression of uncontrollable emotion in a forbidden and composed variety perhaps exhibits the uniqueness of his writings. Hemingway's words are essentially just words like any other words, but the way he blends them together is his unique modus operandi, a stylistic recipe that no other writer has been able to recreate. However, this paper purports to highlight the unique style and technique of Hemingway in his masterpiece, The Old Man and the Sea.
\end{abstract}

Keywords: plausibility, annunciation, dialogic, precision, uncontrollable

\section{INTRODUCTION}

Hemingway's The Old Man and the Sea is a specimen that speaks fervently the dynamics of style and technique. However Green Hills of Africa marks the turning point in Hemingway's narrative technique. It is a first-person narration of Hemingway's African safari, approaching fiction in its form. But the total absence of invention and the reportorial nature of narration disqualify this book from being treated as a novel. The book however, reflects Hemingway's awareness of new dimensions to be achieved in prose-writing and may be described as a turning point in Hemingway's development as a novelist.

\section{NARRATIVE TECHNIQUE}

The stories arising out of his African safari, viz. "The Short Happy life of Francis Macomber" and "The Snows of Kilimanjaro", demonstrate this change in the artist's technique. The most important development is the employment of the third-person viewpoint of the narration. In a sustained narrative like the novel, Hemingway does not use the third-person viewpoint in his pre-safari novels and we find him using it invariably in each of the post-safari novels. He must have become acutely conscious of the limitations of the first-person method and the advantages of the third-person method. Hemingway answered one of John Atkins' questions, on this subject, as follows:

When I wrote the first two novels I had not learned to write in the third-person. The first person gives you great intimacy in attempting to give a complete sense of experience to the reader. It is limited however and in the third-person the novelist can work in other people's heads and in other people's country. His range is greatly extended and so are his obligations. I prepared myself for writing in the third person by the discipline of writing Death in the Afternoon, the short stories and especially the long short stories of 'The Short Happy Life of Francis Macomber' and 'The Snows of Kilimanjaro'. (John Atkin, P. 72-73)

In the first-person method, "the field of vision is defined with perfect distinctness, and his story cannot stray outside it..... It is rounded by the bounds of the narrator's own personal experience." (Percy, P.257) The narrator's defined position has its advantages. It contributes to the intensity and total effect of the story. But as Percy Lubbock points out, it need not be forfeited if the first-person is changed to the third:

The author may use the man's field of vision and keep as faithfully within it as though the man were speaking for himself. In that case he retains this advantage and adds to it another, one that is like to be very much greater. For

\footnotetext{
${ }^{1}$ Corresponding Author: chittarbhoi@gmail.com
} 
now, while the point of view is still fixed in shape, still assigned to the man in the book, it is free in time, there no longer stretches, between the narrator and the events of which he speaks, a certain tract of time, across which the past must appear in a more or less distant perspective. All the variety obtainable by a shifting relation to the story in time is thus in the author's hand, the safe serenity of a far retrospect, the promising of threatening urgency of the present, every gradation between the two, can be drawn into the whole effect of the book, and all of it without any change of the seeing eye. It is a liberty that may keep the story indefinitely, raising this matter into strong relief, throwing that other back into vaguer shade.

Just as Hemingway's experiments in To Have and Have Not lead to the success of For Whom the Bell Tolls, his experiments in Across the River and into the Trees lead to the effective narration of The Old Man and the Sea. The symbolic marlin which is lost in To Have and Have Not, hooked and killed and lashed alongside his skiff in For Whom the Bell Tolls, and lost for the most part to the sharks in Across the River and into the Trees, is finally brought home in The Old Man and the Sea. The damaged condition of the marlin when it is brought ashore is a mark of the struggle endured by the artist in the process. A composite statement of this metaphor is made by Mark Schorer:

It is an old man catching a fish, yes; but it is also a great artist in the act of actually writing about the struggle. Nothing is more important than his craft, and it is beloved, but because it may be struggled with and mastered, it is also a foe, enemy to all self-indulgence, to all looseness of feeling, all laxness of style, all soft pomposities. (Carlos P.134)

The Gulf Stream which is the scene of most of the action in To Have and Have Not is the backdrop of the entire action here, bringing back to our minds Hemingway's statement about it in Green Hills of Africa in relation to his art : “...or when you do something which people do not consider a serious occupation and yet you know, truly, that it is as important and has always been as important as all the things that are in fashion, and when, on the sea, you are alone with it and know that this Gulf Stream you are living with, knowing, learning about, and loving, has moved, as it moves, since before man..."(Green Hills P. 148-149) This theme is dramatized in The Old Man and the Sea which is actually based upon an old fisherman's experience. The old man, who lives with, knows, and loves the Gulf Stream, is alone on it struggling with the marlin and the sharks and the stream. He is beaten at the end "finally and without remedy", and his furled sail more than ever looks "like the flag of permanent defeat". All the while, the stream is there, and the old man's struggles on it form a brief episode. The tourists at the Terrace "looking down in the water among the empty beer cans and dead barracudas" represent the flux of life outside the drama of the old man's heroic struggles on the stream. The contrapuntal theme, which Hemingway has kept in the background so far, finally confronts his and becomes the main subject of a novel. This theme is clearly indicated by the title of the novel.

The narrative situation is reduced to simpler terms than in Across the River and into the Trees with only the old man, the sea, and the denizens of the sea as characters, for the most part, and the narrative focus is almost continually on the old man except for one or two minor shifts as in the description of the Mako shark. The magnitude of the subject which involves the "one single, lasting thing - the stream" necessitates the omniscient point of view of narration. The classical unities are observed here, especially the unity of place, which is the Gulf Stream throughout the main action, and that of action, which is continuous and is remarkably free from any subordinate plot or action. The undeviating focus on the protagonist and the intensity of action and emotional tension make the division of the novel into chapters not only unnecessary but virtually impossible, and give it the look of a long short story rather than of a novel.

\section{DRAMATIZATION OF STORY}

The story is completely dramatized. Hemingway presents the old man, the boy, and the sea in the beginning of the novel and allows the story to unfold itself. As the tempo of the story rises, the omniscient narrator's voice is no longer heard; it becomes the means of showing the action. We become oblivious of the narrator and concentrate on the action. This near elimination of the narrator in the interests of dramatization is an important feature of The Old Man and the Sea.

Santiago is a greatly improved version of Cantwell in some respects. Both Cantwell and Santiago are given to dreaming and romanticism. Santiago's dreams are similar to Cantwell's. Both dream mostly about places. But Santiago's dreams are given greater importance and they form part of the artifact of the novel. His dreams are described in detail in (p. 26-28); in the midst of his struggle with the marlin he dreams of a vast school of porpoises,

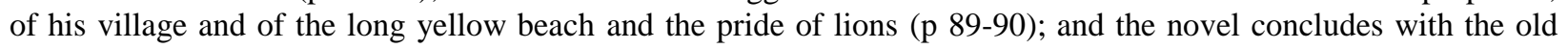


man dreaming about the lions. This quality of dreaming and romanticism is linked up with their "informed illusion". Carlos Baker refers to Cantwell's "informed illusion", and Bickford Sylvester demonstrates that it is present in Santiago also by quoting from the first dialogue between the old man and Manolin, and the omniscient narrator's comment that "they went through this fiction every day."(Modern Fiction P.473)

Cantwell's monologues to the portrait and to sleeping Renata are incongruous with his character and sound ludicrous because his dreams and informed illusion are not properly stressed in the narrative but only briefly referred to in course of dialogues. But the omniscient narrator takes care of this aspect of characterization in The Old Man and the Sea and tells us during the course of the first dialogue between Santiago and Manolin: "There was no cast net and the boy remembered when they had sold it. But they went through this fiction every day. There was no pot of yellow rice and fish and the boy knew this too... The boy did not know whether yesterday's paper was a fiction too" (p.18). A little later, when the boy brings supper, wakes up the old man, and says: "I have not wished to open the container until you were ready, "the old man replies that he is ready: "I only needed time to wash" (p.32). The boy wonders where he washed. The omniscient narrator describes his dreams in vivid detail and comments: "He no longer dreamed of storms, or of women, or of great occurrences, or of great fish, nor flights, nor contests of strength, nor of his wife. He only dreamed of places now and of the lions on the beach. They played like young cats in the dusk and he loved them as he loved the boy. He never dreamed about the boy "(p. 27-28). He never dreams about the boy because he does not have to. It is the boy in him that watches the lions on the African beach: "When I was your age I was before the mast on a square rigged ship that ran to Africa and I have seen lions on the beaches in the evening" (p.24).

This youthful experience is permanently enshrined in his dream-memory. The boy in him thus stays with him and this explains the friendship between him and Manolin. Manolin is an outward manifestation of the boy in him who remains an invisible observer of the beach and the lions and other things in his dreams. During his ordeal, Santiago expresses the wish that he had the boy with him at six different times, and the last time he repeats the wish thrice over with considerable emotion. This happens after the marlin jumps and makes him fall onto the bow with his face in the cut slice of the dolphin. He has been dreaming of the lions on the yellow beach when the fish jumps and wakes him up rudely. His wish for the boy is thus associated with the boy in him too- a romantic yearning for his youthful strength. This romanticism, coupled with his dreams and informed illusion, lends credence to his idiosyncratic way of talking aloud to himself, to the bird, to the marlin and the sharks, and even to his left hand. Besides, the fact that he is all alone on the limitless expanse of waters also explains his desire to hear human voice, albeit his own, and to have some company on the skiff even if it is a bird. Santiago himself reflects on this matter when he realizes that he is talking aloud (p. 43).

It is interesting to note that Santiago stops wishing for the boy after killing the marlin which fills him with a sense of guilt, almost fratricidal: "I am a tired old man. But I have killed this fish which is my brother and now I must do the slave work" (p.105). But occasionally he thinks of DiMaggio, until the scavenger-sharks come and put an end to it. Thus the two images from which he has drawn his supply of inspiration and confidence are no longer available to him in the uneven struggle which follows even as his knife and club, his only weapons, are taken away from him during the course of his fight with the sharks. But he has his tiller left when his other weapons are lost and when the tiller breaks he can still use the splintered butt. So has he got his ability to take punishment and the Christological references continue to the end. These references originate from his sense of identity with the marlin. His thought "I wish I was the fish..." is followed by "He settled comfortably against the wood and took his suffering as it came..." (p.71) this is the first in a series of Calvary references. Like the protagonist of Today is Friday, Santiago is pretty good in there.

The mechanics of narration in this novel chiefly consist in giving the reader a clear, objective view of the drama taking place on the sea while allowing him to involve himself emotionally with what the protagonist thinks and does .As the novel opens, the narrator tells us that Santiago, an experienced old fisherman whose hands bear the marks of handling heavy fish, has gone without a fish for eighty-four days and "everything about him was old except his eyes" which were sea-blue, cheerful, and undefeated (p.10). This significant exception is related to the existence within Santiago of the boy, who sees the pride of lion on the African beach, and a romanticism which explains his 'informed illusion' and well understood and innocuous pretension. We learn from Santiago's reflections early in the book that he loves the sea and her denizens and is gifted with an unusual understanding and compassion. He is sorry for the small birds "that were always flying and looking and almost never finding," wonders why such delicate birds are made when the ocean can be so cruel, and then shows a rare understanding of the cruelty of the ocean also: "But the old man always thought of her as feminine and as something that gave or withheld great favours, and if she did wild or wicked things it was because she could not help them. The moon affects her as it does a woman, he thought" 
(p.33). He has overcome the weakness of anger and this is made clear even earlier when we are told by the omniscient narrator that many of the fisherman on the Terrace "made fun of the old man and he was not angry “(p.11). Cantwell is shown in process of overcoming this weakness and Santiago as completely free from it. Even in his flight with the sharks there is no rancor. He fights like a soldier, admires even the dentuso "who is beautiful and noble and knows no fear of anything": " 'I killed him in self-defense'," the old man said aloud. 'And I killed him well'" (p.117). When the old man does not know what he has against him (p.51), and wonders if it is a marlin one hundred fathoms down in the sea (p.45).The omniscient narrator gives us a panoramic view of the vast scene as Santiago lies forward "cramping himself against the line with all of his body," and dreams of porpoises and lions: "The moon had been up for a longtime but he slept on and the fish pulled on steadily and the boat moved into the tunnel of clouds" (p.90).As Santiago looks at the marlin constantly to make sure that it is true and is blissfully ignorant of the approaching Mako shark, we keep track of the movements of the shark as he comes up from deep down in the water, and swims fast and hard on the course of the skiff ,some time losing the scent and picking it up again (p.110-111).It is this superior point of view that makes us aware of the tragic irony of Santiago who compassionates the flying fish and the bird that have little chance. We know that neither marlin nor dolphin nor shark nor Santiago has any chance against the "one single, lasting thing-the stream."

The emotional tension, which starts rising when the old man feels the pull on the line for the first time, keeps on rising, punctuated by a brief spell of relaxation after each peak, only to be followed by a higher peak of tension. The peaks of tension throughout his struggle with the marlin find their dramatic correlative in the line joining the fisherman and the fish, which becomes to taut that beads of water jump from it and sometimes reach the very edge of the breaking point and pulls down the old man (p. 49,52,59,61,91,95). For some time, Santiago's cramped left hand also serves as a dramatic correlative for the emotional tension in the narrative. When tension reaches its last and highest peak in his struggle with the marlin, Santiago reaches a point when he does not care "who kills who" (p.102).The brief interlude which follows the kill sees the old man lashing the marlin to his skiff, dining on shrimps and convincing himself that it has all truly happened and is not a dream. But the interlude ends when the first the shark appears and from this points onwards the emotional tension shows an upward curve. The curve does not decline, as it normally does, after rising to a peak of tension here, but pauses for a while in its upward journey as the old man waits for more sharks. As the old man shouts "Ay," like one feeling the nail go through his hands, watching the two Galanos, the emotional curve resumes its upward journey. It pauses briefly again when the two sharks are killed and the old man waits for more to come. In this way, the curves shows only brief pauses in its upward motion until it reaches its climax when Santiago flights the sharks desperately in the dark losing his knife and club and breaking his tiller, his only remaining weapon, and knows that he is beaten finally and without remedy. Carlos Baker thinks that "the basic rhythms of the novel, in its maritime sections, are essentially those of the grounds well of the sea." But the emotional rhythm of the novel is not a matter of more "stress-yield, brace-relax alternation." Each stress is followed by a more intense stress unlike the ground well, which does not have a steadily rising tempo punctuated by brief declensions. The basic rhythm is more like the circles made by the marlin, each circle shorter and at a higher level than its predecessor, until, at the end, the marlin rises high out of the water and hangs in the air above the old man before falling dead into the water. The narrative rhythm in The Old Man and the Sea is modeled on concentric circles at different, rising levels culminating in the tension rising higher and higher, without any declension but only brief pauses, until Santiago's dark, desperate battle with the sharks is over.

\section{IRONY AND PARAdOX AS MATRIX}

Hemingway superimposes a paradox over the obvious ironic pattern of this novel. Santiago catches a giant marlin after eighty-four days of unsuccessful fishing on the high seas only to lose most of him to the sharks. His great triumph is reduced to a miserable failure and what he brings home is only the skeleton of the magnificent fish lashed to his skiff. But this basic irony is transformed into a paradox when we consider how the old man fights the sharks with an indomitable will and brings home is prize, though in a bad shape, realizes his "hubris," takes the punishment and achieves true humility, admitting to himself as well as to the boy that he is beaten (p.131,136). Material failure is transmuted into moral and spiritual triumph and Santiago suffers a victorious defeat.

The prize that he brings home finally is humility. The novel presents the spirit of man struggling not only against the marlin and the sharks, but against pride which is ultimately overcome. The contra punctual framework of the old man contending against the vast sea and her denizens far out "Beyond all people in the world" helps in giving a powerful expression to this thematic paradox. Hemingway makes a skilful use of the techniques of point of view and interior monologue in giving an effective expression to his subject. The Old Man and the Sea may be described as a composite expression of Hemingway's basic contrapuntal theme and presents the narrative technique of the post Green Hills of Africa fiction at its best. The story yields to a variety of symbolic interpretations but these are all new 
dimensions which the perceptive critic sees. Even if we are prejudiced against symbolic writing and dislike the habit of reading all kinds of meanings into a writer's work, we still find that the story, by itself, has an absorbing interest and a powerful appeal.

\section{CONCLUSION}

The novel is the best example of Hemingway's unobtrusive art which, without showing itself, does its work on the reader. As Robert P. Weeks points out, Hemingway confers on a seemingly routine experience affecting ordinary people a cosmic significance (Weeks P.15-16). This is nowhere else more true than in The Old Man and the Sea. Undoubtedly the style and technique got readers' approbation.

\section{REFERENCES}

[1] Andre Maurois, "Ernest Hemingway," Hemingway and His Critics: An International Anthology, ed. Carlos Baker, New York: Hill and Wang, 1966 and Philip Young Ernest, Hemingway: A Reconsideration University Park, Pa.: Pennsylvania State University Press, 1966

[2] Atkins John, The Art of Ernest Hemingway: His work and Personality, London: Spring Books, 1952

[3] Baker Carlos "With Grace Under Pressure," Ernest Hemingway: Critiques of Four Major Novels, ed. New York: Charles Scribner's Sons, 1962

[4] Backford Sylvester, “The Old Man and the Sea: Hemingway’s extended vision,” PMLA, 81 March 1966

[5] Baker, Carlos. Ernest Hemingway: The Writer As Artist, $3^{\text {rd }}$ ed. Prinseton, N.J.: Princeton University Press, 1963

[6] Hemingway, Earnest. Green Hills of Africa, New York: Charles Scribner's Sons, 1953

[7] Hemingway, Earnest. See “On the Blue Water: A Gulf Stream Letter,", ed William White New York: Bantam Books, 1968

[8] Hemingway, Earnest. The Old Man and the Sea, New York: Charles Scribner's Sons, 1952

[9] Percy Lubbock, The Craft of Fiction, London : Jonathan Cape,1963

[10] Sean O' Faolain, “A clean well lighted place," Hemingway: A Collection of Critical Essays, ed. Robert P. Weeks (Englewood Cliffs, N.J.: Prentice -Hall, Inc., 1962 